\title{
The Swelling-activated Chloride Channel CIC-2, the Chloride Channel CIC-3, and CIC-5, a Chloride Channel Mutated in Kidney Stone Disease, Are Expressed in Distinct Subpopulations of Renal Epithelial Cells
}

\author{
Nicholas Obermüller, ${ }^{\star}$ Norbert Gretz, ${ }^{\star}$ Wilhelm Kriz, ${ }^{\ddagger}$ Robert F. Reilly, ${ }^{\S}$ and Ralph Witzgall» \\ $*$ Medical Research Center, Klinikum Mannheim, University of Heidelberg, D-68167 Mannheim, Germany; ${ }^{*}$ Institute of Anatomy and Cell \\ Biology I, University of Heidelberg, 69120 Heidelberg, Germany; ${ }^{\S}$ Yale University School of Medicine, Department of Medicine, New \\ Haven, Connecticut 06520
}

\begin{abstract}
The mammalian genome encodes at least nine different members of the ClC family of chloride channels. So far only two of them could be localized on a cellular level in the kidney. We now report on the precise intrarenal localization of the mRNAs coding for the chloride channels $\mathrm{ClC}-2, \mathrm{ClC}-3$ and ClC-5. Expression of ClC-2 mRNA, encoding a swelling-activated chloride channel, could be demonstrated in the $\mathrm{S} 3$ segment of the proximal tubule. The chloride channel ClC-3 mRNA and ClC-5 mRNA, coding for a chloride channel mutated in kidney stone disease, were both expressed in intercalated cells of the connecting tubule and collecting duct. Whereas ClC-3 mRNA expression was most prominent in the cortex of rat kidneys, ClC-5 mRNA was expressed from the cortex through the upper portion of the inner medulla. A detailed analysis revealed that $\mathrm{ClC}-3$ was expressed by type B intercalated cells, whereas ClC-5 was expressed by type A intercalated cells. These findings have important implications for the pathogenesis of hereditary kidney stone disease caused by mutations in the CLCN5 gene. (J. Clin. Invest. 1998. 101:635-642.) Key words: chloride channels • kidney • intercalated cells • nephrolithiasis • genetic disease
\end{abstract}

\section{Introduction}

Chloride channels have attracted a lot of attention in the functional study of a variety of organs, in particular the brain, muscle, and the kidney (for reviews on renal chloride channels see references 1 and 2). They have been implicated in membrane excitability and transepithelial transport. Therefore, it is not surprising that chloride channels not only play an important role in the normal physiology of those organs, but that mutations in their genes have also been found in several diseases. The mammalian genome contains at least nine members of the $C L C N$-family, encoding the chloride channels $\mathrm{ClC}-\mathrm{K} 1, \mathrm{ClC}$ $\mathrm{K} 2$, and $\mathrm{ClC}-1$ to $\mathrm{ClC}-7$. By Northern blot analysis, ClC-K1

\footnotetext{
Address correspondence to Ralph Witzgall, University of Heidelberg, Institute of Anatomy and Cell Biology I, Im Neuenheimer Feld 307, 69120 Heidelberg, Germany. Phone: 49-(0)6221-548686; FAX: 49-(0)6221-544951; E-mail: ralph.witzgall@urz.uni-heidelberg.de

Received for publication 13 August 1997 and accepted in revised form 5 December 1997.
}

J. Clin. Invest.

(C) The American Society for Clinical Investigation, Inc. 0021-9738/98/02/0635/08 \$2.00

Volume 101, Number 3, February 1998, 635-642

http://www.jci.org and $\mathrm{ClC}-\mathrm{K} 2$ are expressed exclusively in the kidney $(3,4)$, whereas ClC-2 (5), -3 (6), -4 (7, 8), -5 (9, 10), -6 (11) and -7 (11), besides their expression in the kidney, have also been found in other organs. $\mathrm{ClC}-1$ is exclusively expressed in muscle (12) and mutations in the gene coding for $\mathrm{ClC}-1$ are the cause for myotonia congenita (13). Of the nine $\mathrm{ClC}$ chloride channels which have been cloned, only $\mathrm{ClC}-\mathrm{K} 1$ and $\mathrm{ClC}-\mathrm{K} 2$ could be localized by immunohistochemistry in the kidney $(14,15)$.

This study describes the precise localization of the mRNAs coding for three additional chloride channels: $\mathrm{ClC}-2, \mathrm{ClC}-3$ and $\mathrm{ClC}-5$, in the adult rat kidney. Previous reports have shown that the activity of the $\mathrm{ClC}-2$ chloride channel can be regulated by changes in the osmolality of the environment (16). This feature is of particular interest in the kidney, where profound changes of osmolality are known to occur. The $\mathrm{ClC}-3$ chloride channel was identified by a homology-based PCR cloning strategy; it is abundantly expressed in the brain and in the kidney (6). Mutations in the CLCN5 gene have been associated with several syndromes displaying nephrolithiasis such as Dent's disease, X-linked recessive hypophosphatemic rickets, and X-linked recessive nephrolithiasis (17), as well as a familial hypercalciuric Fanconi-like syndrome (18). The aim of our study, therefore, was to localize the $\mathrm{ClC}-2, \mathrm{ClC}-3$, and $\mathrm{ClC}-5$ chloride channels in the kidney.

\section{Methods}

Animals. Male adult Sprague-Dawley rats (70-100 d old) were kept under standard laboratory conditions in the Animal Care Facility in Mannheim. Animals had free access to rat chow, containing 19\% protein, and tap water.

Perfusion-fixation. For optimal preservation of tissue morphology and tissue RNA content, adult Sprague-Dawley rats were perfused retrogradely through the distal abdominal aorta. Perfusion was conducted at a pressure level of $210-220 \mathrm{mmHg}$ with $2 \%$ freshly dissolved paraformaldehyde (PFA) in PBS, $\mathrm{pH}$ 7.4, for 3 min and subsequently with a $18 \%$ sucrose solution in PBS, adjusted to $800 \mathrm{mOs}-$ $\mathrm{mol} / \mathrm{kg}$, for another $3 \mathrm{~min}$ at the same pressure level. After removal, kidneys were cut into slices, mounted quickly onto small pieces of Styrofoam, and then snap-frozen in liquid nitrogen-cooled isopentane. All tissues were stored at $-80^{\circ} \mathrm{C}$ until further use.

Preparation of riboprobes. cDNA fragments of rat ClC-2 (1.8kbp fragment) (5), -3 (1.8-kbp fragment) (6), and -5 (3.0-kbp fragment) (10) showing only limited homology to each other or other chloride channels (no cross-reactivity was observed on Northern blots) were subcloned into pBluescript (Stratagene $\mathrm{GmbH}$, Heidelberg, Germany).

To generate sense and antisense RNA probes for in situ hybridization experiments, the plasmids were restricted appropriately. In vitro transcription was carried out according to the protocol supplied by the manufacturer (Boehringer Mannheim, Mannheim, Germany). The lengths of the digoxigenin-labeled riboprobes were checked on a denaturing formaldehyde agarose gel stained with ethidium bromide. 
Transcripts were finally subjected to partial alkaline hydrolysis to obtain fragments of a calculated average length of 250 nucleotides.

Nonradioactive in situ hybridization. In situ hybridization was essentially carried out as described previously (19). Cryostat sections (5-7 $\mu \mathrm{m}$ thick) were transferred onto silane-coated glass slides. Sections were postfixed in $4 \%$ paraformaldehyde (in PBS, $\mathrm{pH}$ 7.4) for $20 \mathrm{~min}$, rinsed three times in PBS, and washed in DEPC-treated, bidestilled water for $10 \mathrm{~min}$. In order to improve permeabilization, a mild deproteinization step was performed by immersing slides in $0.1 \mathrm{M}$ $\mathrm{HCl}$ for $10 \mathrm{~min}$, followed by two short rinses (5 min each) in PBS. To reduce background, slides were acetylated for $20 \mathrm{~min}$ in $0.1 \mathrm{M}$ triethanolamine, $\mathrm{pH} 8.0$, containing $0.25 \%$ acetic anhydride, added immediately before starting this step. After rinsing in PBS, slides were dehydrated for 5 min each in 70, 80, and $95 \%$ ethanol, respectively, and air-dried for $20 \mathrm{~min}$. A prehybridization step was carried out by incubating sections with prehybridization solution $(50 \%$ deionized formamide; $50 \mathrm{mM}$ Tris-HCl, pH 7.6; $25 \mathrm{mM}$ EDTA, $\mathrm{pH}$ 8.0; $20 \mathrm{mM}$ $\mathrm{NaCl} ; 0.2 \%$ SDS; $0.25 \mathrm{mg} / \mathrm{ml}$ tRNA from yeast; and $2.5 \times$ Denhardt's solution). Sections were placed in a moist chamber and incubated at $42^{\circ} \mathrm{C}$ for $2 \mathrm{~h}$. Meanwhile, hydrolyzed riboprobes were diluted in deionized formamide, boiled for $2 \mathrm{~min}$, and chilled on ice. Subsequently, the individual components of the hybridization mixture were added and mixed vigorously (final concentrations were: $50 \%$ deionized formamide; $20 \mathrm{mM}$ Tris-HCl, $\mathrm{pH}$ 7.6; $1 \mathrm{mM}$ EDTA, $\mathrm{pH}$ 8.0; 0.33 $\mathrm{M} \mathrm{NaCl} ; 0.2 \mathrm{M}$ DTT; $0.5 \mathrm{mg} / \mathrm{ml}$ tRNA; $0.1 \mathrm{mg} / \mathrm{ml}$ sonicated, denatured DNA from fish sperm; $1 \times$ Denhardt's solution; and $10 \%$ dextran sulfate). Concentration of labeled sense or antisense probe was $\sim 10$ ng per $\mu l$ hybridization mixture. After removal of prehybridization solution, $25 \mu \mathrm{l}$ of hybridization mixture were applied to each section and carefully covered with a siliconized coverslip. Hybridization was performed at $42^{\circ} \mathrm{C}$ in a moist chamber for $16 \mathrm{~h}$. Washing procedures included a first washing step in $2 \times \mathrm{SSC}(1 \times \mathrm{SSC}=150 \mathrm{mM} \mathrm{NaCl}$; $15 \mathrm{mM}$ sodium citrate, $\mathrm{pH} \mathrm{7.0)}$ at room temperature for $20 \mathrm{~min}$, followed by three stringent washes at $49^{\circ} \mathrm{C}(1 \mathrm{~h}$ each $)$ in $1 \times \mathrm{SSC} ; 0.5 \times$ SSC; and $0.1 \times$ SSC, each containing $50 \%$ formamide. Slides were then rinsed at room temperature in $0.5 \times \mathrm{SSC}$ for $15 \mathrm{~min}$, again rinsed in $0.2 \times \mathrm{SSC}$ for $10 \mathrm{~min}$ and equilibrated twice for $5 \mathrm{~min}$ in buffer I (100 mM Tris-HCl; $150 \mathrm{mM} \mathrm{NaCl}, \mathrm{pH} 7.4)$.

Sections were then covered with blocking medium (buffer I containing 1\% blocking reagent [Boehringer Mannheim, Mannheim, Germany] and $0.5 \% \mathrm{BSA}$ ) and incubated for $30 \mathrm{~min}$ at room temperature in a moist chamber. Blocking solution was then drained from the slides and a polyclonal alkaline phosphatase-coupled sheep antidigoxigenin antibody (diluted 1:500 in blocking medium) was applied to the sections. After an incubation of $2 \mathrm{~h}$ at room temperature the sections were incubated overnight at $4^{\circ} \mathrm{C}$. The next morning sections were washed twice for $15 \mathrm{~min}$ in buffer I and equilibrated for $2 \mathrm{~min}$ in buffer II (100 mM Tris- $\mathrm{HCl}, \mathrm{pH} 9.5 ; 100 \mathrm{mM} \mathrm{NaCl} ; 50 \mathrm{mM} \mathrm{MgCl}$ ). For signal development a substrate solution (buffer II containing $0.417 \mathrm{mM}$ nitro blue tetrazolium chloride, NBT [predissolved in $70 \%$ dimethylformamide]; $0.406 \mathrm{mM}$ 5-bromo-4-chloro-3-indolyl-phosphate, 4-toluidine salt; BCIP or X-phosphate [predissolved in 100\% dimethylformamide]; and $1 \mathrm{mM}$ levamisol [to inhibit remaining endogenous alkaline phosphatase activity]) was freshly prepared. After covering sections with large amounts of substrate solution, slides were kept at $4^{\circ} \mathrm{C}$ in a moist chamber in the dark. Color reaction was controlled under the microscope and terminated (usually after 12-24 h) by immersing the slides twice for $5 \mathrm{~min}$ in buffer III $(100 \mathrm{mM}$ Tris$\mathrm{HCl}, 1 \mathrm{mM}$ EDTA, $\mathrm{pH}$ 8.0). After rinsing in PBS, sections were mounted in bicarbonate-buffered glycerol, $\mathrm{pH}$ 8.6.

Combined in situ hybridization and immunocytochemistry. To identify specifically the sites of $\mathrm{ClC}-3$ and $\mathrm{ClC}-5$ mRNA expression, kidney sections were first probed with the respective antisense RNA as described in the regular in situ hybridization protocol and then subjected to immunohistochemistry with the following antibodies: a guinea pig polyclonal antibody against the basolateral $\mathrm{Na}^{+} / \mathrm{Ca}^{2+}$-exchanger was used as a marker for the connecting tubule (20), intercalated cells were detected with a polyclonal antibody against the kidney-specific
56-kD subunit of the $\mathrm{H}^{+}$-ATPase (21), and principal cells in the collecting duct were identified with a polyclonal antibody against aquaporin-2 (22).

After the color development to detect specific transcripts was complete, the sections were washed in PBS and then blocked in PBS/ $2 \%$ BSA $/ 0.1 \%$ Triton X-100 for 30 min. Primary antibodies were diluted in PBS/2\% BSA (1:200 in the case of the antibodies against the $\mathrm{Na}^{+} / \mathrm{Ca}^{2+}$-exchanger and $\mathrm{H}^{+}$-ATPase, and 1:50 in the case of the antibody against aquaporin-2). The sections were incubated with the primary antibodies overnight at room temperature and then rinsed twice in PBS for 10 min each. The Cy3-coupled (Dianova, Hamburg, Germany) and FITC-coupled (Sigma-Aldrich Chemie GmbH, Deisenhofen, Germany) secondary antibodies were applied for $1 \mathrm{~h}$, after
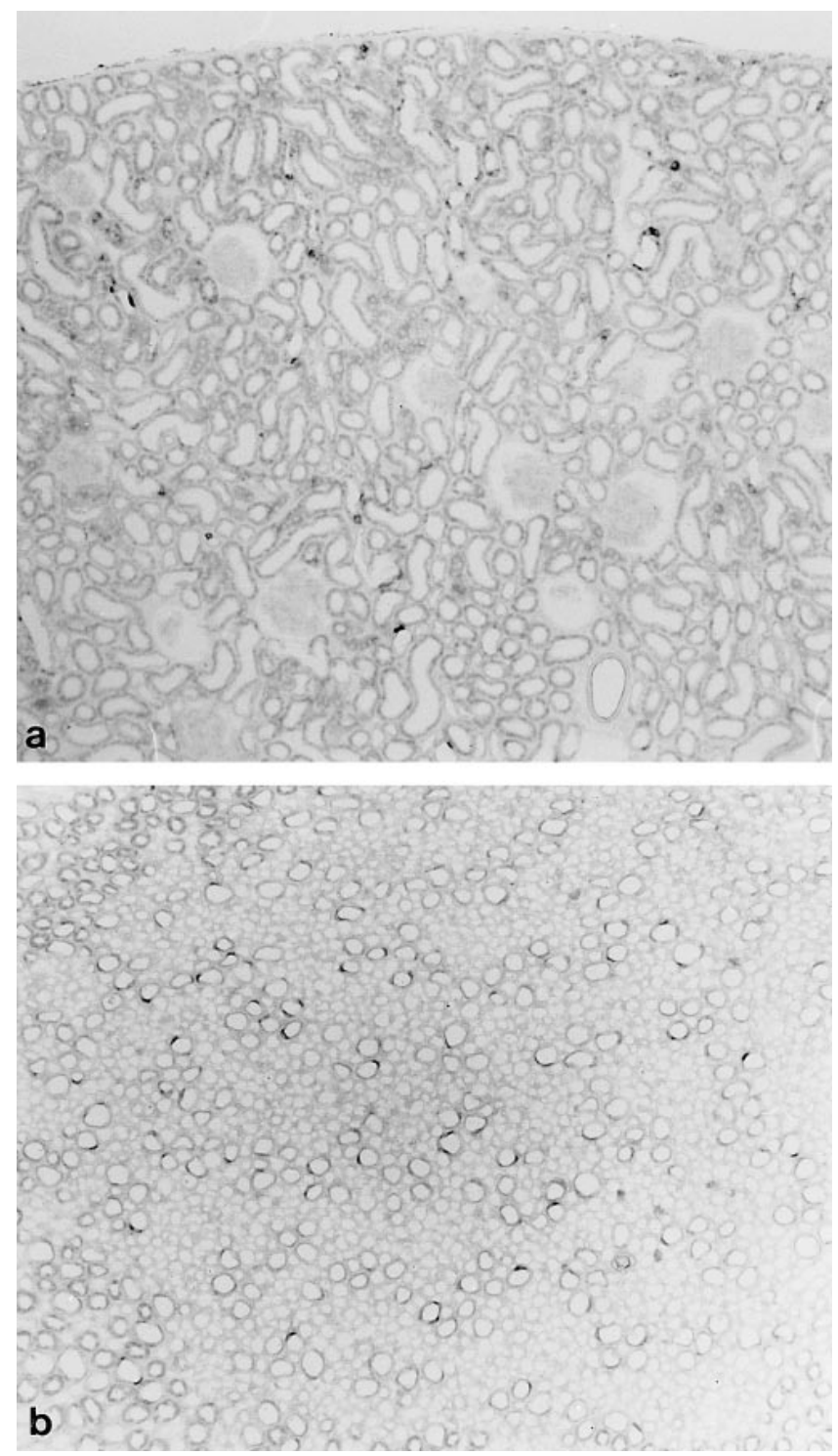

Figure 1. Overview of the expression of ClC-5 mRNA in the adult rat kidney. The ClC-5 mRNA was detected with a digoxigenin-labeled antisense RNA by in situ hybridization. A section through the cortex shows labeling of dispersed cells in profiles representing collecting ducts and connecting tubules $(a)$. A cross section through the upper third of the inner medulla $(b)$ demonstrates numerous collecting ducts which contain cells with a strong expression of ClC-5 mRNA. $a$, $\times 60 ; b, \times 75$. 
which the sections were rinsed and mounted in carbonate-buffered glycerol. For simultaneous labeling with the antibodies against the $\mathrm{H}^{+}$-ATPase and the $\mathrm{Na}^{+} / \mathrm{Ca}^{2+}$-exchanger, both primary antibodies were applied at the same time before being detected with Cy3- and FITC-coupled secondary antibodies.

Controls. The specificity of the obtained in situ hybridization signal was verified by parallel incubation with antisense and sense riboprobes on alternate sections. Throughout all experiments sense probes did not produce any detectable signal. As further negative controls some sections were hybridized without antisense probe, while others were processed by omission of anti-DIG antibody. Both controls yielded completely negative results.

\section{Results}

The chloride channels $\mathrm{ClC}-3$ and $\mathrm{ClC}-5$ are located in intercalated cells of the adult rat kidney. In order to learn more about the possible pathogenetic mechanism underlying the formation of kidney stones, we carried out nonradioactive in situ hybridization with digoxigenin-labeled $\mathrm{ClC}-5$ antisense RNA. At a low magnification, a very restricted staining pattern was noticed in tubular profiles from the cortex through the upper third of the inner medulla in the adult rat kidney (Fig. 1). As will be outlined below, these profiles represent connecting tubules and collecting ducts. The finding that only a portion of cells in a given profile displayed a signal was consistent with the notion that intercalated cells expressed ClC-5. To confirm this hypothesis, the same sections were incubated with an antibody against the kidney-specific $56 \mathrm{kD}$ subunit of $\mathrm{H}^{+}$-ATPase subsequent to the in situ hybridization with $\mathrm{ClC}-5$ antisense RNA (this particular subunit of $\mathrm{H}^{+}$-ATPase is exclusively expressed in intercalated cells [21]). $\mathrm{H}^{+}$-ATPase immunoreactivity and the in situ hybridization signal overlapped to a large extent towards the inner medulla, but only to a minor extent in the cortex (Fig. 2). Only those intercalated cells which showed an apical staining with the anti- $\mathrm{H}^{+}$-ATPase antibody also expressed $\mathrm{ClC}-5$ mRNA, thus identifying those cells as type $\mathrm{A}$ intercalated cells, whereas type B intercalated cells did not express ClC-5 mRNA (Fig. 2). Principal cells, which were identified with an antibody against aquaporin-2 (22), also were devoid of an in situ hybridization signal (Fig. 3). The distribution of ClC-5 expressing cells is consistent with the fact that type A intercalated cells are present from the cortex through the upper portion of the inner medulla, whereas type B intercalated cells prevail in the cortex and are absent in the inner stripe and inner medulla (23). Because coexpression of ClC-5
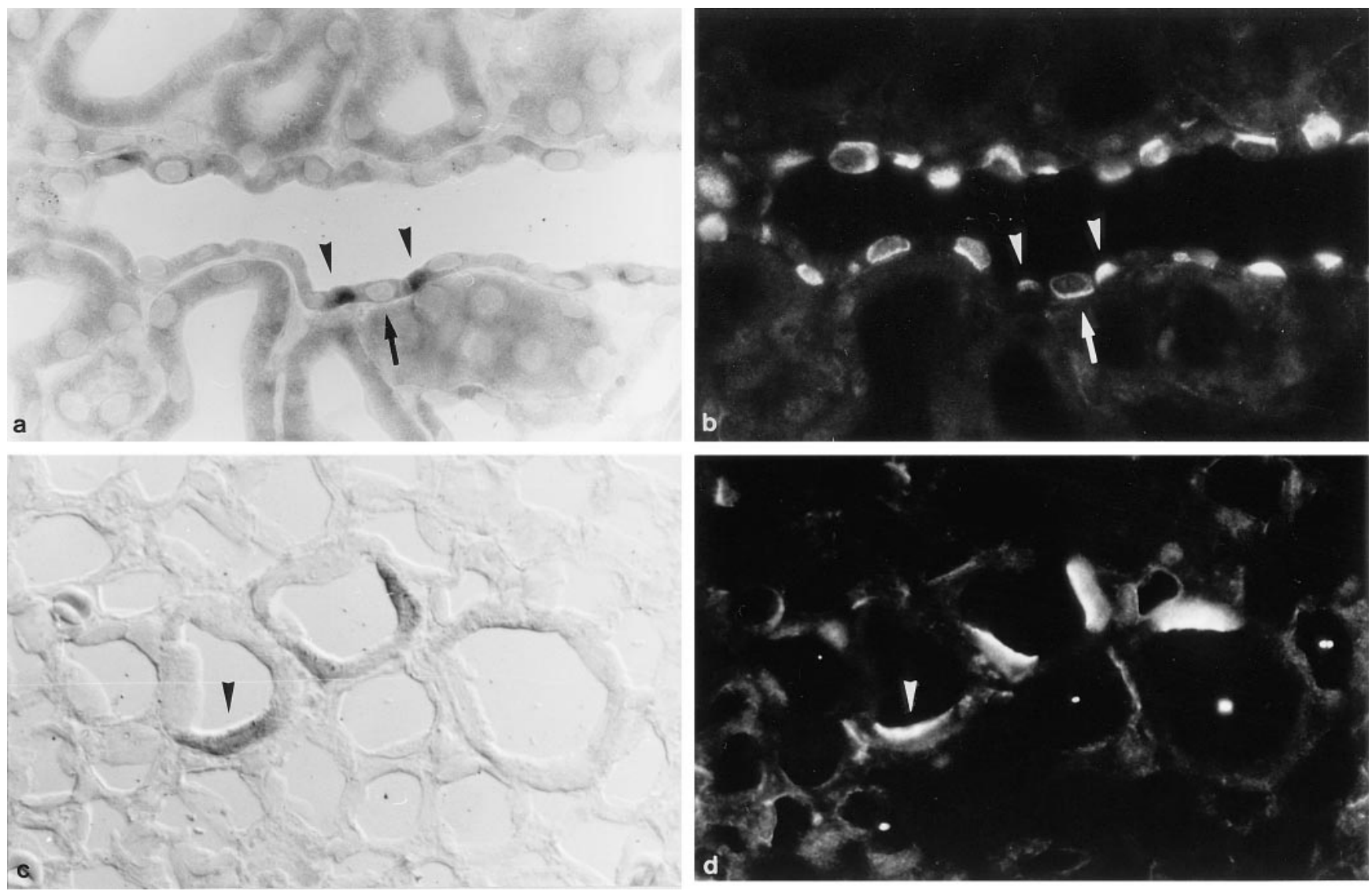

Figure 2. In situ hybridization with ClC-5 antisense RNA ( $a$ and $c$ ) and subsequent immunohistochemical staining of the same section with an antibody against the kidney-specific 56-kD subunit of $\mathrm{H}^{+}$-ATPase $(b$ and $d$ ) (cortical collecting duct in $a$ and $b$, inner medullary collecting duct profiles in $c$ and $d$ ). As marked by arrowheads in $a$ and $b, \mathrm{ClC}-5$ mRNA is expressed by intercalated cells with an apical location of $\mathrm{H}^{+}-\mathrm{ATPase}$, identifying those cells as type A intercalated cells. Type B intercalated cells with a basolateral or diffuse expression of $\mathrm{H}^{+}$-ATPase are negative for ClC-5 mRNA (arrow in $a$ and $b$ ). This correlates well with the expression of ClC-5 mRNA in the upper portion of the inner medulla ( $c$ and $d$ ), because type B intercalated cells are not present in the inner medullary collecting duct of the rat (an example of a ClC-5 mRNA positive type A intercalated cell is highlighted with an arrowhead in $c$ and $d$ ). $a$ and $b, \times 465 ; c$ and $d, \times 670$. 


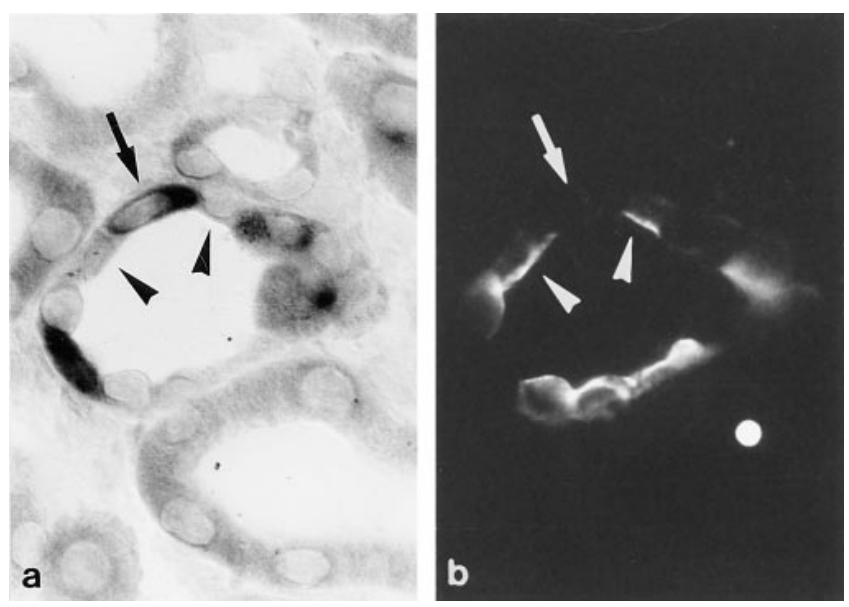

Figure 3. ClC-5 mRNA is not expressed in principal cells of the collecting duct. Double labeling of the same section with digoxigeninlabeled ClC-5 antisense RNA $(a)$ and an antibody against aquaporin-2, a marker for principal cells of the collecting duct $(b)$, reveals the mutually exclusive expression of $\mathrm{ClC}-5$ and aquaporin-2 in a cortical collecting duct profile. An intercalated cell expressing ClC-5 mRNA (arrow) is flanked by two principal cells which express aquaporin-2 but not ClC- 5 mRNA (arrowheads). $a$ and $b, \times 520$.

mRNA and $\mathrm{H}^{+}$-ATPase was also seen in profiles which resemble connecting tubules, sections probed with $\mathrm{ClC}-5$ antisense RNA were also stained with an antibody against the $\mathrm{Na}^{+}$/ $\mathrm{Ca}^{2+}$-exchanger (the $\mathrm{Na}^{+} / \mathrm{Ca}^{2+}$-exchanger is a marker for the connecting tubule [20]). Fig. 4 illustrates that intercalated cells of the connecting tubule, but not connecting tubule cells themselves expressed ClC-5 mRNA. Apart from its location in intercalated cells, we could not detect a clear-cut in situ hybridization signal at other sites, although after a prolonged exposure a faint signal could be seen in proximal tubules.

The chloride channel ClC-3 was identified by a homologybased PCR cloning strategy (6). Although ClC-3 mRNA is
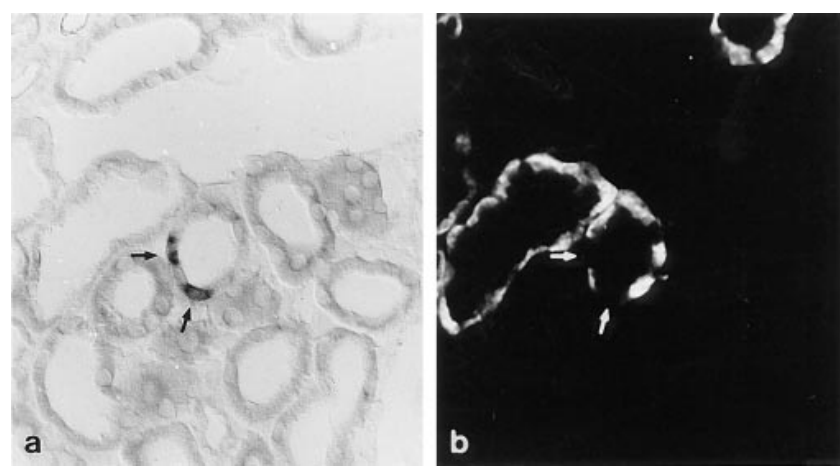

Figure 4. ClC-5 mRNA is also expressed in intercalated cells of the connecting tubule. The same section was first subjected to in situ hybridization with a ClC-5 antisense RNA $(a)$ and then examined immunohistochemically with an antibody against the $\mathrm{Na}^{+} / \mathrm{Ca}^{2+}$ exchanger, which labels connecting tubule cells $(b)$. Those cells expressing ClC-5 mRNA do not express the $\mathrm{Na}^{+} / \mathrm{Ca}^{2+}$-exchanger (arrows in $a$ and $b$ ), which identifies them as intercalated cells of the connecting tubule. $a$ and $b, \times 200$. most strongly expressed in the central nervous system, there also is a reasonable amount of ClC-3 mRNA in the kidney (6). When sections from adult rat kidneys were probed with $\mathrm{ClC}-3$ antisense RNA, a signal was seen in the cortex and the outer stripe, but again only a subpopulation of cells in a given tubular profile expressed $\mathrm{ClC}-3 \mathrm{mRNA}$. The number of positive cells was high in the cortex, but decreased in the outer stripe (Fig. 5). No in situ hybridization signal could be demonstrated in the inner stripe and inner medulla. Staining of the same sections with the antibody against the $56 \mathrm{kD}$ subunit of $\mathrm{H}^{+}$-ATPase revealed that intercalated cells expressed ClC-3 mRNA. In contrast to our finding with $\mathrm{ClC}-5$, however, those intercalated cells which expressed ClC-3 mRNA were labeled basolaterally or diffusely cytoplasmic, identifying them as type B intercalated cells (Fig. 6, $a$ and $b$ ). Principal cells did not express $\mathrm{ClC}-3$ mRNA (Fig. 6, $c$ and $d$ ). Intercalated cells of connecting tubules also expressed ClC-3 mRNA as demonstrated by staining of those tubular profiles with the antibody against the $\mathrm{Na}^{+}$/ $\mathrm{Ca}^{2+}$-exchanger. Connecting tubule cells, which were identified by their expression of the $\mathrm{Na}^{+} / \mathrm{Ca}^{2+}$-exchanger, did not express ClC-3 mRNA (Fig. 7).

The swelling-regulated chloride channel ClC-2 is expressed in the $S 3$ segment of the proximal tubule. In the rat, the highest ClC-2 mRNA levels have been demonstrated in the brain and kidney. Interestingly, $\mathrm{ClC}-2$ channel activity can be regulated by changes in environmental osmolality (16). Nonradioactive in situ hybridization with a ClC-2 antisense RNA resulted in a labeling of the outer stripe and the deep portions of medullary rays (Fig. $8 a$ ). A high power micrograph demonstrates that only those tubular profiles with a brush border expressed ClC-2 mRNA, thus clearly identifying the site of $\mathrm{ClC}-2$ expression as the $\mathrm{S} 3$ segment of the proximal tubule (Fig. $8 b$ ).

\section{Discussion}

At least two types of intercalated cells can be discerned in the connecting tubules and collecting ducts, the acid-secreting type A intercalated cells and the bicarbonate-secreting type B intercalated cells (23). In the type A intercalated cell, an $\mathrm{H}^{+}$-ion is secreted into the lumen and the remaining $\mathrm{HCO}_{3}{ }^{-}$-anion is transported via the $\mathrm{HCO}_{3}{ }^{-} / \mathrm{Cl}^{-}$-exchanger into the interstitium. These ion fluxes create an ion imbalance in the cell and one, therefore, has to postulate that the incoming chloride ion has to leave the cell again through a channel. The same holds true for the type B intercalated cell, which secretes bicarbonate through an as yet unidentified $\mathrm{HCO}_{3}{ }^{-} / \mathrm{Cl}^{-}$-exchanger into the lumen, whereas the $\mathrm{H}^{+}$-ion leaves the cell on the basolateral side with the help of the proton pump. Previous studies have identified chloride channels via patch-clamp techniques in intercalated cells (24-26). We extend those electrophysiological studies by demonstrating the expression of the mRNAs encoding the $\mathrm{ClC}-3$ and $\mathrm{ClC}-5$ chloride channels in type $\mathrm{B}$ and type A intercalated cells, respectively. Because our studies are based on nonradioactive in situ hybridization, we do not know the distribution of the proteins in the cell. It is tempting to speculate, however, that the restricted expression pattern of the mRNAs also is reflected by the sorting of the respective proteins.

Recently, mutations in the CLCN5 gene have been found in various disorders characterized by kidney stone disease and 


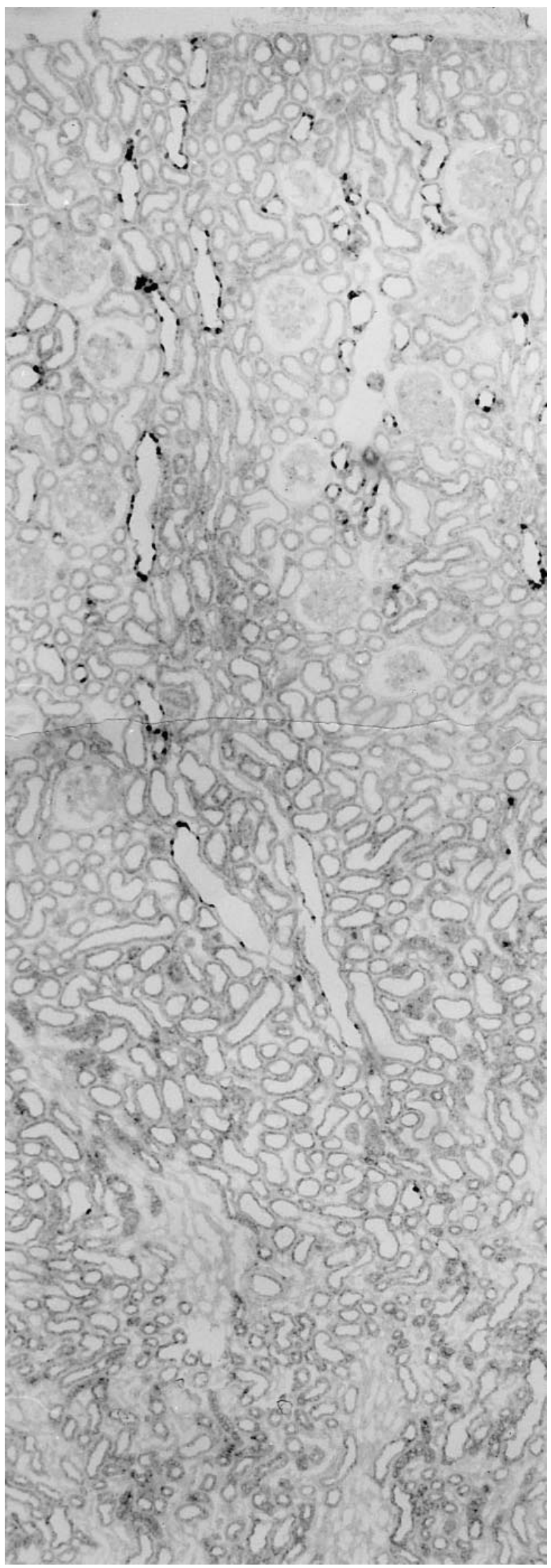

low molecular weight proteinuria $(17,18)$. The precise role of $\mathrm{ClC}-5$ in the pathogenesis of those disorders has so far remained a matter of speculation. In our study, we could reproducibly detect the $\mathrm{ClC}-5 \mathrm{mRNA}$ only in type A intercalated cells and only occasionally in the proximal tubule, which one would expect as a site of $\mathrm{ClC}-5$ expression because of the symptom of low molecular weight proteinuria. The proximal tubule is the nephron segment where the filtered peptides are reabsorbed, so that it can be argued that a chloride channel is part of the endocytotic vesicles (which are acidified by the $\mathrm{H}^{+}$ATPase) in order to provide a counterion for the transported protons. A decreased flow of chloride ions into the endocytotic vesicles would thus lead to a decreased acidification of those vesicles and subsequently to inefficient reabsorption of low molecular weight peptides. Intercalated cells on the other hand, which express another isoform of the hydrogen ion transport protein $\mathrm{H}^{+}$-ATPase, are responsible for the regulation of acid secretion in connecting tubules and collecting ducts. A mutation in the CLCN5 gene could lead to dysfunctional proton secretion in type A intercalated cells because of the lack of accompanying flow of chloride ions. Patients with X-linked recessive nephrolithiasis present with hyperphosphaturia (27), so that kidney stone formation in those patients may be enhanced by the higher than usual protein concentration and a higher local $\mathrm{pH}$ due to lower $\mathrm{H}^{+}$secretion by type $\mathrm{A}$ intercalated cells (28).

The ClC-3 mRNA is strongly expressed in type B intercalated cells of the kidney, and the $\mathrm{ClC}-3$ chloride channel may therefore represent the functional correlate of ClC-5. Similar to the situation encountered in type A intercalated cells, ClC-3 may serve to counteract the ion imbalance caused by the secretion of bicarbonate ions into the lumen. It will be interesting to find out whether both channels are sorted to the same side or to opposite sides of the cell membrane, and whether any syndromes can be attributed to mutations in the CLCN3 gene.

We could demonstrate that the mRNA encoding the swelling-activated chloride channel $\mathrm{ClC}-2$ is expressed in the $\mathrm{S} 3 \mathrm{seg}$ ment of the adult kidney. Our study extends the observation of Murray et al. (29) who analyzed the expression of the $\mathrm{ClC}-2$ protein in E19 and newborn rat kidneys. Previously, it has been shown that $\mathrm{ClC}-2$ activity increased after exposure of cells to hypotonicity (16). Interestingly, the mRNA coding for ROSIT, a putative renal osmotic stress-induced transporter (30), and the mRNA coding for the taurine transporter (31) also are expressed in the S3 segment of the proximal tubule. The osmolality in the kidney increases at the border between the cortex and the outer stripe, so that it can be assumed that the distribution of the ClC-2 chloride channel, ROSIT and the taurine transporter mirrors this change of osmolality. Future studies are needed to address the specific functions of those proteins.

Figure 5. Overview of the expression of ClC-3 mRNA in the adult rat kidney. Sections from the adult rat kidney were hybridized with a digoxigenin-labeled ClC-3 antisense RNA. Strong hybridization signals were found in numerous, yet dispersed cells in the cortex and the outer stripe. The number of positive cells decreased in the outer stripe, correlating with the known distribution of type B intercalated cells. $\times 60$.

Expression of ClC Chloride Channels in the Kidney 

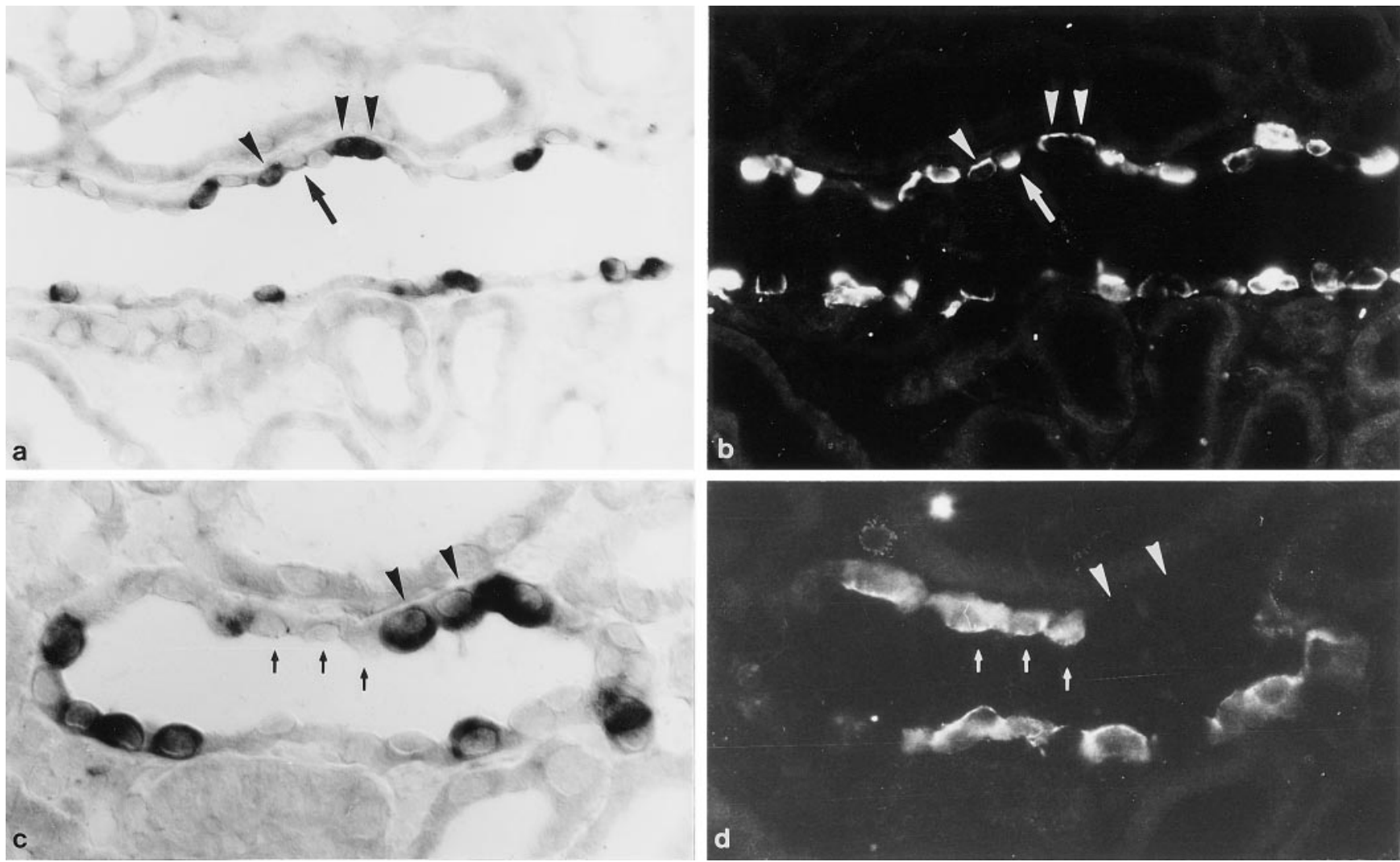

Figure 6. ClC-3 mRNA is expressed in type B intercalated cells, but not in type A intercalated cells and principal cells of collecting ducts. Cortical sections of adult rat kidney were first hybridized with $\mathrm{ClC}-3$ antisense RNA $(a, c)$ and subsequently stained with an antibody against the kidney-specific 56-kD subunit of $\mathrm{H}^{+}$-ATPase $(b)$ and aquaporin-2 $(d)$. Those cells, which expressed ClC-3 mRNA, showed a basolateral or diffuse staining with the antibody against $\mathrm{H}^{+}$-ATPase, identifying them as type B intercalated cells (arrowheads in $a$ and $b$ ). Type A intercalated cells were devoid of an in situ hybridization signal (large arrows in $a$ and $b$ ). Principal cells, which were identified by the expression of aquaporin-2 (small arrows in $c$ and $d$ ), did not express ClC-3 mRNA, whereas intercalated cells did (arrowheads in $c$ and $d$ ). $a$ and $b, \times 300 ; c$ and $d, \times 485$.

It has become clear from previous observations and from this report, that $\mathrm{ClC}$ chloride channels such as $\mathrm{ClC}-\mathrm{K} 1(14,15)$ and ClC-K2 (15) and non-ClC chloride channels such as CFTR $(29,32)$ are expressed at diverse sites along the nephron and in the collecting duct. These particular locations probably reflect the different requirements for those channels in the kidney. Further research will be needed in order to clarify how this heterogeneity in expression translates into functional characteristics.

\section{Acknowledgments}

The kind gifts of ClC-cDNAs from Thomas Jentsch, and antibodies from Dennis Brown (anti-aquaporin-2 antibody), and Stephen Gluck
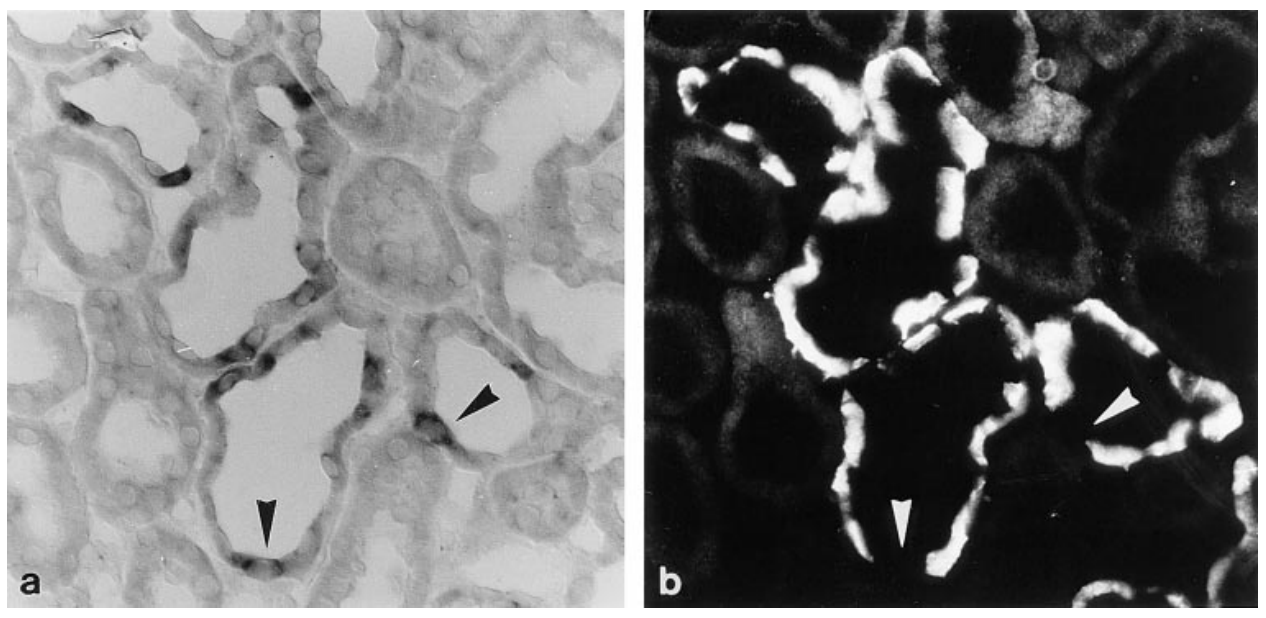

Figure 7. Expression of $\mathrm{ClC}-3$ mRNA in intercalated cells of connecting tubules. A section through the cortex of an adult rat kidney was first probed with $\mathrm{ClC}-3$ antisense RNA ( $a$ ) and subsequently stained immunohistochemically with an antibody against the $\mathrm{Na}^{+} / \mathrm{Ca}^{+}$exchanger, which identifies connecting tubule cells $(b)$. ClC-3 mRNA was expressed by cells which were unreactive with the anti- $\mathrm{Na}^{+} / \mathrm{Ca}^{+}-$ exchanger antibody, thus identifying intercalated cells as the sites of ClC-3 expression (arrowheads). a and $b, \times 225$. 

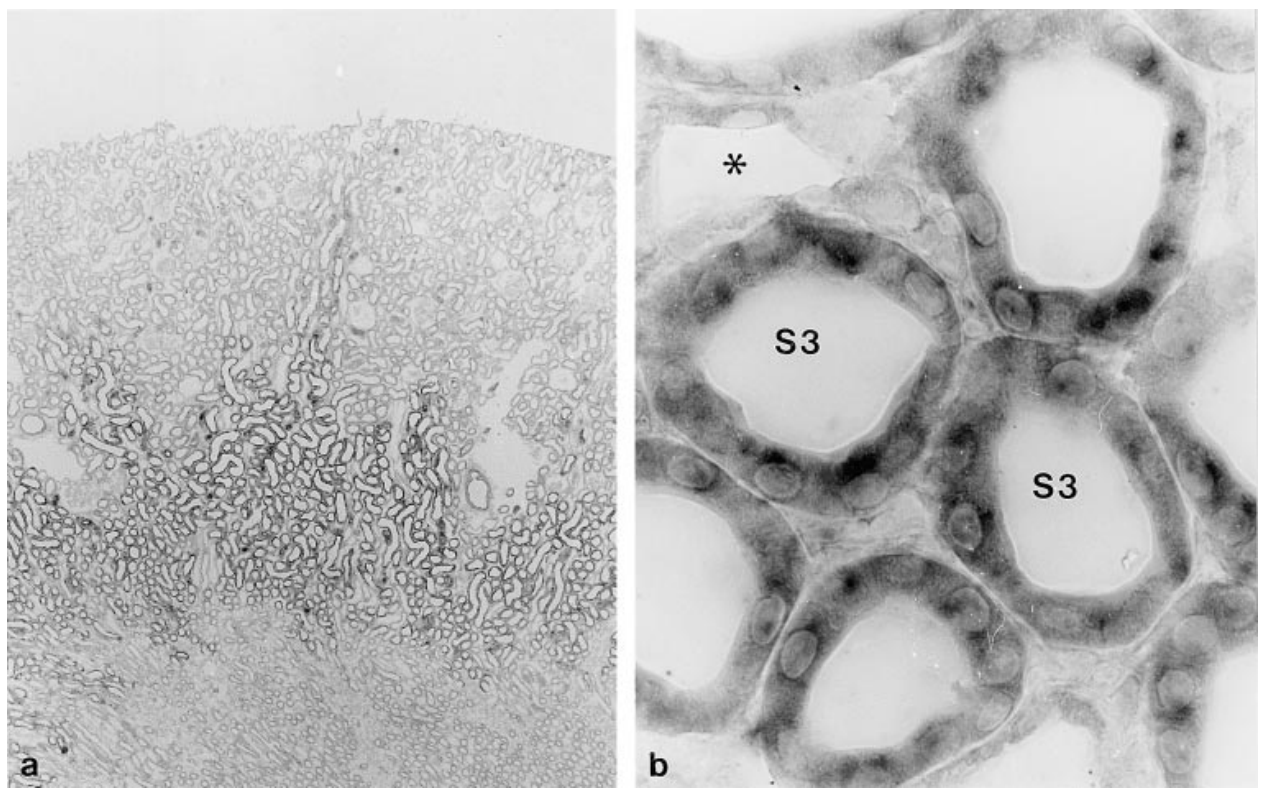

Figure 8. ClC-2 mRNA is expressed in the $\mathrm{S} 3$ segment of the proximal tubule. An overview of a section from an adult rat kidney subjected to in situ hybridization with digoxigeninlabeled ClC-2 antisense RNA reveals positive tubular profiles in the outer stripe and deep portions of medullary rays $(a)$. A high-power micrograph of the outer stripe demonstrates that the in situ hybridization signal is present in tubular profiles with a brush border, which identifies them as the $\mathrm{S} 3$ segment of the proximal tubule $(S 3$ in $b)$. Adjacent tubular profiles, probably representing thick ascending limbs, do not express ClC- 2 mRNA ( $*$ in $b) . a$, $\times 20 ; b, \times 485$.

(anti- $\mathrm{H}^{+}$-ATPase antibody) are gratefully acknowledged. We thank Ingrid Ertel for skillful photographical work.

We also want to acknowledge financial support from the Forschungsfonds der Fakultät für Klinische Medizin Mannheim der Universität Heidelberg.

\section{References}

1. Uchida, S., and F. Marumo. 1996. Molecular characterization of chloride channels in the kidney. Exp. Nephrol. 4:135-138.

2. Reeves, W.B., and T.E. Andreoli. 1992. Renal epithelial chloride channels. Annu. Rev. Physiol. 54:29-50.

3. Kieferle, S., P. Fong, M. Bens, A. Vandewalle, and T.J. Jentsch. 1994. Two highly homologous members of the $\mathrm{ClC}$ chloride channel family in both rat and human kidney. Proc. Natl. Acad. Sci. USA. 91:6943-6947.

4. Uchida, S., S. Sasaki, T. Furukawa, M. Hiraoka, T. Imai, Y. Hirata, and F. Marumo. 1993. Molecular cloning of a chloride channel that is regulated by dehydration and expressed predominantly in kidney medulla. J. Biol. Chem. 268: 3821-3824.

5. Thiemann, A., S. Gründer, M. Pusch, and T.J. Jentsch. 1992. A chloride channel widely expressed in epithelial and non-epithelial cells. Nature. 356:57-60.

6. Kawasaki, M., S. Uchida, T. Monkawa, A. Miyawaki, K. Mikoshiba, F. Marumo, and S. Sasaki. 1994. Cloning and expression of a protein kinase $\mathrm{C}$-regulated chloride channel abundantly expressed in rat brain neuronal cells. Neuron. 12:597-604.

7. Jentsch, T.J., W. Günther, M. Pusch, and B. Schwappach. 1995. Properties of voltage-gated chloride channels of the ClC gene family. J. Physiol. 482: 19S-25S

8. van Slegtenhorst, M.A., M.T. Bassi, G. Borsani, M.C. Wapenaar, G.B. Ferrero, L. de Conciliis, E.I. Rugarli, A. Grillo, B. Franco, H.Y. Zoghbi, and A. Ballabio. 1994. A gene from the Xp22.3 region shares homology with voltagegated chloride channels. Hum. Mol. Genet. 3:547-552.

9. Sakamoto, H., M. Kawasaki, S. Uchida, S. Sasaki, and F. Marumo. 1996. Identification of a new outwardly rectifying $\mathrm{Cl}^{-}$channel that belongs to a subfamily of the $\mathrm{ClC} \mathrm{Cl}^{-}$channels. J. Biol. Chem. 271:10210-10216.

10. Steinmeyer, K., B. Schwappach, M. Bens, A. Vandewalle, and T.J. Jentsch. 1995. Cloning and functional expression of rat CLC-5, a chloride channel related to kidney disease. J. Biol. Chem. 270:31172-31177.

11. Brandt, S., and T.J. Jentsch. 1995. ClC-6 and ClC-7 are two novel broadly expressed members of the CLC chloride channel family. FEBS Lett. 377:15-20.

12. Steinmeyer, K. C. Ortland, and T.J. Jentsch. 1991. Primary structure and functional expression of a developmentally regulated skeletal muscle chloride channel. Nature. 354:301-304.

13. Koch, M.C., K. Steinmeyer, C. Lorenz, K. Ricker, F. Wolf, M. Otto, B. Zoll, F. Lehmann-Horn, K.-H. Grzeschik, and T.J. Jentsch. 1992. The skeletal muscle chloride channel in dominant and recessive human myotonia. Science. 257:797-800.

14. Uchida, S., S. Sasaki, K. Nitta, K. Uchida, S. Horita, H. Nihei, and F. Marumo. 1995. Localization and functional characterization of rat kidney-specific chloride channel, ClC-K1. J. Clin. Invest. 95:104-113.

15. Vandewalle, A., F. Cluzeaud, M. Bens, S. Kieferle, K. Steinmeyer, and T.J. Jentsch. 1997. Localization and induction by dehydration of ClC-K chloride channels in the rat kidney. Am. J. Physiol. 272:F678-F688.

16. Gründer, S., A. Thiemann, M. Pusch, and T.J. Jentsch. 1992. Regions involved in the opening of $\mathrm{ClC}-2$ chloride channel by voltage and volume. Nature. 360:759-762.

17. Lloyd, S.E., S.H.S. Pearce, S.E. Fisher, K. Steinmeyer, B. Schwappach, S.J. Scheinman, B. Harding, A. Bolino, M. Devoto, P. Goodyer, et al. 1996. A common molecular basis for three inherited kidney stone diseases. Nature. 379: 445-449.

18. Lloyd, S.E., S.H.S. Pearce, W. Günther, H. Kawaguchi, T. Igarashi, T.J. Jentsch, and R.V. Thakker. 1997. Idiopathic low molecular weight proteinuria associated with hypercalciuric nephrocalcinosis in Japanese children is due to mutations of the renal chloride channel (CLCN5). J. Clin. Invest. 99:967974.

19. Obermüller, N., P. Bernstein, H. Velazquez, R. Reilly, D. Moser, D.H. Ellison, and S. Bachmann. 1995. Expression of the thiazide-sensitive $\mathrm{NaCl}$ cotransporter in rat and human kidney. Am. J. Physiol. 269:F900-F910.

20. Reilly, R.F., C.A. Shugrue, D. Lattanzi, and D. Biemesderfer. 1993. Immunolocalization of the $\mathrm{Na}+/ \mathrm{Ca} 2+$ exchanger in rabbit kidney. Am. J. Physiol. 265:F327-F332.

21. Nelson, R.D., X.-L. Guo, K. Masood, D. Brown, M. Kalkbrenner, and S Gluck. 1992. Selectively amplified expression of an isoform of the vacuolar $\mathrm{H}^{+}$. ATPase 56-kilodalton subunit in renal intercalated cells. Proc. Natl. Acad. Sci. USA. 89:3541-3545.

22. Sabolic, I., T. Katsura, J.-M. Verbavatz, and D. Brown. 1995. The AQP-2 water channel: effect of vasopressin treatment, microtubule disruption, and distribution in neonatal rat. J. Membr. Biol. 143:165-175.

23. Kaissling, B., and W. Kriz. 1992. Morphology of the loop of Henle, distal tubule and collecting duct. In Renal Physiology. Vol. 1. E.E. Windhager, editor. Oxford University Press, Oxford. 109-167.

24. Light, D.B., E.M. Schwiebert, G. Fejes-Tóth, A.N. Fejes-Tóth, K.H. Karlson, F.V. McCann, and B.A. Stanton. 1990. Chloride channels in the apical membrane of cortical collecting duct cells. Am. J. Physiol. 258:F273-F280.

25. Koeppen, B.M. 1985. Conductive properties of the rabbit outer medullary collecting duct: inner stripe. Am. J. Physiol. 248:F500-F506.

26. Koeppen, B.M. 1986. Conductive properties of the rabbit outer medullary collecting duct: outer stripe. Am. J. Physiol. 250:F70-F76.

27. Frymoyer, P.A., S.J. Scheinman, P.B. Dunham, D.B. Jones, P. Hueber, and E.T. Schroeder. 1991. X-linked recessive nephrolithiasis with renal failure. N. Engl. J. Med. 325:681-686.

28. Hruska, K.A., J.R. Seltzer, and M. Grieff. 1997. Nephrolithiasis. In Diseases of the Kidney. Vol. I. R.W. Schrier, and C.W. Gottschalk, editors. Little, Brown and Company, Boston. 739-765. 
29. Murray, C.B., S. Chu, and P.L. Zeitlin. 1996. Gestational and tissue-specific regulation of ClC-2 chloride channel expression. Am. J. Physiol. 271:L829L837.

30. Obermüller, N., B. Kränzlin, R. Verma, N. Gretz, W. Kriz, and R. Witzgall. 1997. Renal osmotic stress-induced cotransporter: expression in the newborn, adult and post-ischemic rat kidney. Kidney Int. 52:1584-1592.

31. Matsell, D.G., T. Bennett, X. Han, A.M. Budreau, and R.W. Chesney.
1996. Expression and regulation of the taurine transporter gene in the S3 segment of the proximal tubule. J. Am. Soc. Nephrol. 7:1302 (Abstr.).

32. Crawford, I., P.C. Maloney, P.L. Zeitlin, W.B. Guggino, S.C. Hyde, H. Turley, K.C. Gatter, A. Harris, and C.F. Higgins. 1991. Immunocytochemical localization of the cystic fibrosis gene product CFTR. Proc. Natl. Acad. Sci. USA. 88:9262-9266. 